\title{
LÍNGUA PORTUGUESA: UM OBJETO CIRCUNSCRITO
}

\section{ERNESTO SÉRGIO BERTOLDO; JOÃO DE DEUS LEITE}

\author{
Programa de Pós-Graduação em Estudos Linguísticos - UFU \\ Av. João Naves de Ávila, 2121 - 38404-144 - Santa Mônica - Uberlândia-MG - Brasil \\ Mestrado Profissional em Letras - PROFLETRAS (Rede Nacional) - UFT \\ Av. Paraguai, s/n - 77824-838 - Setor Cimba - Araguaína-TO - Brasil \\ esbertoldo@gmail.com ; joaodedeusleite@hotmail.com
}

\begin{abstract}
Resumo. Este artigo aborda a circunscrição da Língua Portuguesa, como objeto de ensino e de aprendizagem, no cenário educacional brasileiro, na Educação Básica. Nessa circunscrição, interessa-nos pensar e problematizar os horizontes da política linguística que se constituiu em relação à Língua Portuguesa. Horizontes esses sensíveis às exigências e às urgências que se apresentaram ao sistema educacional brasileiro a cada momento histórico. Para tanto, recorremos a diferentes diretrizes oficiais, com o intuito de mostrar o processo de institucionalização em relação ao modo como o ensino de Língua Portuguesa deveria se orientar, em termos de referenciais pedagógicos. De modo mais detido, reportamo-nos aos Parâmetros Curriculares Nacionais (PCN), do Ensino Fundamental, para dimensionar como a Língua Portuguesa ganhou uma circunscrição, em termos discursivos. Nesse processo de institucionalização, enfocamos, de modo mais enfático, a relação que a gramática tradicional assumiu no âmbito das diretrizes oficiais, tendo por base a perspectiva de que seu ensino tradicional deveria ser ressignificado. Este artigo aborda, também, alguns dizeres de um professor da Educação Básica, do Ensino Fundamental, como maneira de analisar os possiveis efeitos que essas diretrizes imprimem na composição da Língua Portuguesa, como objeto de trabalho do professor. No trabalho de análise, mostramos que alguns princípios da Linguística moderna ganham operação, quando do momento em que o professor precisa enunciar sobre a sua prática docente. E, em sua enunciação falada, a gramática normativa ganha um lugar já afetado por esses princípios. ̇̀ luz da perspectiva discursiva de orientação pecheutiana, interessa-nos pensar que as diretrizes oficiais, incluindo aí os PCN, produzem discursividades, podendo gerar entre professor e as diretrizes uma identificação teórico-procedimental. Sob uma visada discursiva, vamos mostrar que essa identificação não é pressuposta nem plena e bem-sucedida. Ao contrário, ela é contraditória e conflituosa. Ela não é fruto de um subjetivismo.
\end{abstract}

Palavras-chave: diretrizes oficiais; gramática normativa; texto; discursivizações.

\footnotetext{
${ }^{1}$ Doutor em Linguística Aplicada (Unicamp). Docente no Programa de Pós-Graduação em Estudos Linguísticos da Universidade Federal de Uberlândia, onde também atua na Graduação (ILEEL/UFU).

${ }^{2}$ Doutor em Estudos Linguísticos (UFU). Docente na Universidade Federal de Tocantins, onde atua tanto na Graduação quanto no Mestrado Profissional em Letras (PROFLETRAS, Rede Nacional).
} 


\begin{abstract}
This article approaches the Portuguese Language taken as an object of teaching and learning in the educational Brazilian context. It is our aim to discuss the policies that guide the work proposed in the teaching of Portuguese. In order to achieve such a goal, we have examined official guidelines meant to institutionalize the pedagogical work concerning the teaching of Portuguese. Specifically, we have analyzed the national curriculum parameters (PCN), what made possible to see how this process of institutionalization has taken place. The analysis allowed us to focus on the role normative grammar played in the parameters. It was our perspective that the teaching of normative grammar should be understood differently. The article also analyses some utterances produced by a Portuguese teacher as a way to identify if and how the official guidelines would have affected the method the teacher would use in order to approach normative grammar in the classroom. We came to the conclusion that some principles of modern Linguistics are used in order to reframe the teaching of normative grammar. This was especially realized by listening to the way the teacher talked about his own practice. Thus, the teaching of normative grammar was certainly affected by the principles of modern Linguistics present in the official guidelines. In order to achieve our objectives, theoretically, we followed the discursive perspective as understood by Pêcheux. We stated that the official guidelines, including the PCN, produce discourses and can generate between teachers and the guidelines themselves theoretical and procedural identification. Under a discursive guidance, we showed that this identification is not a pressuposition. Instead, it is contradictory and conflicting. It is not the result of a subjectivism.
\end{abstract}

Keywords: official guidelines; normative grammar; text; discursive practices.

Já esqueci a língua em que comia,
em que pedia para ir lá fora,
em que levava e dava pontapé,
a língua, breve língua entrecortada
do namoro com a prima.

O português são dois; o outro mistério.

(Drummond, 1996, p. 20)

\title{
1. Introdução
}

Neste artigo, mostramos o modo como alguns documentos oficiais voltados para o ensino de Língua Portuguesa, no Brasil, circunscrevem-na, como objeto de ensino e de aprendizagem. Também vamos mostrar o modo como essa circunscrição produziu efeitos para a prática docente, tendo por base a enunciação falada de um professor, considerando a entrevista que realizamos com ele. Iremos conceder um lugar de destaque para os Parâmetros Curriculares Nacionais (PCN, doravante), do Ensino Fundamental, nesse movimento de circunscrição. É que o professor entrevistado por nós, como mostramos por meio de alguns trechos da entrevista abordados, concede um papel para os PCN. Além 
disso, a própria área de Língua Portuguesa da escola à qual o professor é filiado busca alinhar suas práticas pedagógicas à perspectiva dos PCN. É preciso ressaltar que essa entrevista compôs um procedimento de coleta de material mais amplo, por ocasião de uma pesquisa de doutoramento (LEITE, 2015).

A proposição desses documentos nasce da necessidade de se construir, sobretudo a partir da década de 1980, certas referências nacionais para o ensino de Língua Portuguesa e, notadamente, para (re)colocar em outros termos o ensino tradicional de leitura e de escrita. Trata-se, nesse caso específico, do ensino que ganhou fundamento a partir da gramática normativa. E essa proposição, no cenário educacional brasileiro, ganhou relevância e alcance, em termos de política linguística, já que se passou a institucionalizar o modo como deveria ser o ensino de Língua Portuguesa.

Buscou-se, sendo os documentos uma instância de divulgação e de circulação, fazer chegar até o professor certos conhecimentos que advêm de estudos linguísticos modernos, vislumbrando a ressignificação do ensino tradicional. Nessa medida, esses documentos passam a se configurarem, em tese, como objeto que poderia integrar o trabalho do professor. Entretanto, o objeto de trabalho do professor não está reduzido a eles. Muito mais que em sua perspectiva normativa, os documentos deveriam ser tomados em sua perspectiva formadora, no sentido de que a compilação das ideias linguísticas que eles apresentam precisam ser pensadas e problematizadas. É que, da parte do professor, há um movimento de leitura e de interpretação a ser feito em relação aos documentos, o que coloca em jogo um processo de identificação a ser construído. Não se trata de pensar em um processo que se constitui do nada. $\mathrm{O}$ fato de recorrermos a diferentes diretrizes oficiais, tendo aí os PCN um destaque, evidencia que a busca pela ressignificação do ensino tradicional de gramática normativa possui uma ancoragem histórica. Há uma historicidade que habilita a produção de certos sentidos sobre a gramática normativa e sobre o ensino considerado tradicional.

No caso dos PCN em questão, a possibilidade de mudanças do ensino tradicional encontrou respaldo a partir da perspectiva de que os "gêneros de texto", para usarmos a terminologia constante dos PCN, encerrariam os horizontes necessários para a mudança. É que essa perspectiva pôs em relação uma outra concepção de linguagem, conforme salientaremos mais adiante, priorizando a atividade discursiva a que o aluno estaria exposto socialmente. $\mathrm{O}$ ensino de conhecimentos gramaticais sob a forma descontextualizada, na escola, passou a ser condenado sob o argumento de que a gramática normativa está embasada em regras incoerentes e em ocorrências inconsistentes.

A poder desse argumento, muitas discursividades foram produzidas em relação ao ensino de Língua Portuguesa. São discursividades que passaram a expressar um lugar discursivo sobre esse ensino. $\mathrm{O}$ ensino tradicional de gramática normativa deveria ser abandonado. A menção declarada da terminologia da gramática, nas aulas de Língua Portuguesa, deveria ser evitada. O tão propalado exercício de classificação gramatical, a partir de ocorrências linguísticas descontextualizadas, deveria ser afastado das aulas de Língua Portuguesa. A gramática, sob os efeitos do imaginário ${ }^{3}$ que sobre ela produziu

\footnotetext{
${ }^{3}$ Estamos trabalhando com a noção lacaniana de imaginário ( $c f$. LACAN, 1974-1975). Trata-se da instância que ancora a produção de sentido e o estabelecimento de certos lugares aos fatos; uma ordenação que busca organizar os fatos, cujo fundamento é o efeito do todo.
} 
discursividades, trouxe consigo as marcas do mal-estar. Ela passou a trazer consigo as marcas do horror, se considerarmos o (não) lugar que se atribui a ela. Para dizermos da perspectiva teórica a que nos filiamos, neste artigo, a gramática normativa se constituiu, como um material que toca o recalque. O recalque é a operação psíquica de se colocar uma significação de lado ( $c f$. CHEMAMA, 1993). A gramática normativa, eclipsada em seu ensino tradicional, sob a égide dos PCN, foi colocada de lado. E, em seu lugar, mobilizaram o texto, como ponto de partida e de chegada para as aulas de Língua Portuguesa.

Ao produzirmos essa associação entre gramática normativa e recalque, a partir de uma leitura dos fundamentos da Psicanálise freudo-lacaniana, estamos marcando a perspectiva de que há uma recusa inicial em relação à gramática normativa em seu ensino tradicional. E essa recusa acaba por incidir sobre a gramática normativa em si, fazendo uma certa fixação, em muitos casos, entre ela e seu ensino, que se deu a perceber como tradicional. Alude-se à gramática normativa a partir dessa fixação, implicando o retorno das marcas do mal-estar mencionado anteriormente. Coloca-se outra instância no lugar do ensino tradicional de gramática normativa, que é o texto, de modo a contrair uma relação com a instância substituída. Há uma relação de nunca a acabar entre essas instâncias. Esse retorno leva à (re)atualização de certas discursividades sobre o ensino de Língua Portuguesa, tendo a gramática normativa como um material que toca o recalque.

Muitos conhecimentos linguísticos modernos serviram de base para sustentar essa centralidade no texto, quando do mo(vi)mento de se defender o trabalho de leitura e de escrita em sala a partir do texto. No intuito de se pensar na relação entre teoria e prática, dada a natureza de projeção dos PCN, a apropriação que foi produzida diante desses conhecimentos linguísticos implicou deslocamentos, rupturas e modificações dos conhecimentos, acarretando uma fragmentação e uma simplificação das ideias linguísticas constantes dos PCN, por exemplo. Como abordaremos nas reflexões que se seguem, essa centralidade no texto está em função muito mais de aspectos políticos, sociais e econômicos que em virtude de razões teóricas em si.

Assim, os PCN nascem com o compromisso de se reverter o fracasso escolar dos alunos que a escola passou a receber a partir da década de 1970. Os PCN, portanto, configuram como um documento oficial de referência para o ensino, tendo em vista a intervenção do Estado no currículo escolar. Essa intervenção acaba por expor a constituição da Língua Portuguesa, na condição de objeto de ensino e de aprendizagem, a uma contingência histórica e política. A Língua Portuguesa é um objeto mediado, seja em que instância for, cuja circunscrição imaginária aponta para um tensionamento entre o ensino tradicional de gramática normativa e o ensino de leitura e de escrita a partir do texto. Há uma historicidade que habilita e que marca essa circunscrição, de maneira que os professores precisam se haver com essa historicidade. Quando formos analisar e problematizar alguns trechos, em forma de Recortes Discursivos (RD), da entrevista concedida por um professor da educação básica, vamos perceber que ele não está isento desse tensionamento. É que os PCN se apresentam a ele, como documento que produz discursividades sobre o seu objeto de trabalho, e frente a seu objeto de trabalho o professor precisa exercer uma posição discursivo-enunciativa.

Sob um viés discursivo, a fundamentação teórico-analítica deste artigo parte da premissa de que os documentos oficiais integram a produção e a constituição do 
imaginário sobre o ensino de Língua Portuguesa. Esses documentos, por serem objetos simbólicos e serem vinculados a discursividades oficiais, integram uma organização coletiva sobre esse ensino, podendo modificar e afetar a prática pedagógica dos professores. Contudo, para além dessa organização coletiva, é preciso pensar na perspectiva de que essas discursividades não funcionam sem a articulação a uma prática contingencial sustentada e bancada por um sujeito. Essas discursividades ganham uma (re)atualização a partir da prática pedagógica específica, mostrando que esse (não) lugar que a gramática assume não é uma construção que nasce do nada. Como temos dito, neste artigo, há uma historicidade que faz constituir novos horizontes e engastes em relação ao ensino de Língua Portuguesa, tendo como ponto conflituoso o ensino de gramática normativa, eclipsada em seu ensino tradicional.

Consideremos, a seguir, as reflexões em torno da constituição da Língua Portuguesa como objeto de ensino e de aprendizagem, tendo em vista os efeitos do referido tensionamento.

\section{Da instância do documento oficial}

O Ensino Básico ${ }^{4}$ de Língua Portuguesa, no Brasil, passou a contar, no final da década de 90, com a influência de orientações pedagógicas contidas em documentos governamentais específicos. Na Educação Infantil, por meio do documento Referencial Curricular Nacional para a Educação Infantil - Conhecimento de Mundo (1998), os conteúdos de Língua Portuguesa foram integrados ao eixo Linguagem Oral e Escrita, recebendo um tratamento articulado a outros eixos temáticos, como a Música e as Artes Visuais, por exemplo. No Ensino Fundamental e no Ensino Médio, a partir de documentos diferentes, os conteúdos de Língua Portuguesa foram individualizados, tendo por base a construção de referências curriculares nacionais específicas para cada etapa de ensino. Denominados de Parâmetros Curriculares Nacionais (PCN), o documento da área de Língua Portuguesa do Ensino Fundamental foi proposto em 1998, e o documento do Ensino Médio foi publicado em 2000. Neste último documento, os conteúdos de Língua Portuguesa passaram a ser vinculados à área Linguagens, Códigos e suas Tecnologias, já que o Ensino Médio, no país, sofreu uma reformulação em termos de redimensionamento das áreas de ensino e de aprendizagem.

É comum, nesses documentos governamentais, a tarefa de apresentar ao professor princípios para o trabalho pedagógico com a Língua Portuguesa no sistema escolar. A proposição desses documentos, acima de tudo, é fruto da necessidade de se delinear referências nacionais para o ensino e a aprendizagem de Língua Portuguesa, buscando-se uma integração programática para essa disciplina em cada etapa de ensino. Resultantes de reflexões entre pesquisadores da área da linguagem e professores do Ensino Básico, sendo consequência, portanto, de discussões estabelecidas em grupos específicos de trabalho, esses documentos projetam certo perfil de professor ao ensino de Língua Portuguesa. Seja em termos de formação teórica, seja em termos de formação pedagógica, espera-se que o professor reúna condições para pôr em prática uma modalidade de ensino

\footnotetext{
${ }^{4}$ Fixada pela Lei de Diretrizes e Bases da Educação Básica (LDB), Lei no 9.394/1996, a Educação Básica, no Brasil, organiza-se em três etapas, quais sejam: a Educação Infantil, o Ensino Fundamental e o Ensino Médio.
} 
que esteja embasada no trabalho constante com a natureza multifacetada da linguagem, ou seja, no trabalho com a linguagem verbal e não-verbal.

Considerando o aspecto cumulativo do conhecimento e a sua progressão ao longo das etapas de ensino, o trabalho com a natureza heterogênea da linguagem ganha uma distribuição longitudinal no Ensino Básico. Assim, é demandada do professor uma gestão do currículo escolar ao qual sua prática está vinculada, buscando respeitar, por um lado, as especificidades que cada etapa de ensino compreende e, por outro, o continnum natural do conhecimento. Elege-se inicialmente um currículo globalizante para o Ensino Básico, e, para o curso dos ciclos de cada etapa de ensino, privilegia-se um currículo mais específico. Desse modo, a área de Língua Portuguesa deve centrar-se na transversalidade do conhecimento, de modo a assegurar a formação integral de cidadão do aluno.

Por princípio, dada a natureza de disciplina pertencente à base nacional comum do Ensino Básico, a Língua Portuguesa deve contemplar e favorecer o desenvolvimento da competência discursiva e da competência textual do aluno, tendo em vista exatamente a abordagem didático-pedagógica acerca da natureza multifacetada da linguagem. As Diretrizes Curriculares Nacionais Gerais para a Educação Básica (2010), consoantes às bases legais anteriores ao ano de sua publicação, ressaltam a natureza da "base nacional comum na Educação Básica”, por meio do caput, do Artigo 14. Consideremos, a seguir, o caput desse artigo:

A base nacional comum na Educação Básica constitui-se de conhecimentos, saberes e valores produzidos culturalmente, expressos nas políticas públicas e gerados nas instituições produtoras do conhecimento científico e tecnológico; no mundo do trabalho; no desenvolvimento das linguagens; nas atividades desportivas $\mathrm{e}$ corporais; na produção artística; nas formas diversas de exercício da cidadania; e nos movimentos sociais. (BRASIL, 2010, p. 6)

Portanto, a organização curricular do ensino de Língua Portuguesa, em termos de proposição de conteúdos, e as orientações didático-pedagógicas para o Ensino Básico sempre se basearam nos princípios legais de que a Língua Portuguesa se constitui como um componente fundamental da formação escolar. Por isso, conforme é possível notar no caput desse artigo e, sobretudo, nos documentos governamentais anteriormente citados, a aprendizagem da Língua Portuguesa pode oportunizar e favorecer a relação do aluno com o mundo e com a cultura que se produz e se compartilha na sociedade.

A proposição dos PCN, sobretudo o do Ensino Fundamental, em 1998, insere-se em um contínuo de preocupações mais amplas que passou a marcar o movimento de reformulação do ensino de Língua Portuguesa no país. Desde a década de 70, buscava-se a melhoria da qualidade do ensino de Língua Portuguesa, no Brasil, já que os índices de fracasso escolar eram sensíveis nessa década. Nos primeiros ciclos de ensino, o fracasso era referente à dificuldade de alfabetização dos alunos. Nos ciclos finais, o fracasso era concernente à não proficiência dos alunos em relação à linguagem escrita. Na tentativa de reverter esse fracasso escolar, entre as décadas de 60 e 70, ressaltou-se a necessidade de repensar os modos de ensino de Língua Portuguesa, portanto, as metodologias de ensino, em proveito dos conteúdos em si. 
Se considerarmos a Lei n ${ }^{\circ} 5692 / 71$, é possível perceber a ênfase dada à expressão oral e à expressão escrita do aluno, como maneira de proporcionar o aprimoramento de sua comunicação e de sua expressão. Nessa medida, os conteúdos gramaticais deveriam ser tomados como um meio para o desenvolvimento da capacidade de comunicação e de expressão do aluno e, não, como um fim em si mesmo. Não se tratava de um ensino pautado nas regras gramaticais pelas regras gramaticais.

As transformações sociais do Brasil imprimiram um novo ritmo às práticas sociais de leitura e de escrita, bem como uma mudança de formação do público que a escola passou a receber. E, consequentemente, o ensino de Língua Portuguesa necessitava atender à demanda que se constituiu com esse novo ritmo. Assim, a partir da década de 80, o ensino de Língua Portuguesa passa a contar com um perfil de aluno que já não possuía familiaridade com a variedade padrão nem com as bases culturais que a escola tomava por princípio. E a reformulação desse ensino, no país, necessitava levar em consideração essa mudança de perfil, de modo a incorporar as novas condições culturais e linguísticas do Brasil. Segundo Pereira (2005, p. 14-15),

já nos primeiros anos da década de 80 , o ensino da disciplina Português
sofre severas críticas, seja por parte dos que advogam a volta aos
parâmetros tradicionais do ensino, seja por parte dos que denunciavam
os problemas de leitura e de escrita. Não podemos nos esquecer que é
nesse período que se afirma a democratização do ensino da escola; já
iniciada na década anterior; ou seja, as camadas populares conquistaram
seu direito à escolarização e, como bem lembra Soares (1998), já não
são somente os filhos das camadas privilegiadas que demandam escola,
mas as crianças pertencentes às camadas populares, que trazem para
sala de aula a inusitada presença de padrões culturais e variantes
linguísticos diferentes daqueles com que a escola estava habituada a
conviver.

Como iniciativa governamental, uma comissão nacional de especialistas da área da linguagem foi constituída, por meio do decreto $\mathrm{n}^{\circ} 91.372$, de 26/06/85, com a tarefa de lançar um novo olhar para o ensino de Língua Portuguesa. Para tanto, essa comissão teria de propor um conjunto de diretrizes que aprimorasse e que aperfeiçoasse o ensino e a aprendizagem de Língua Portuguesa no país. Assim, como fruto do trabalho da comissão nacional, foram elaboradas as Diretrizes para o aperfeiçoamento do ensino/aprendizagem da Língua Portuguesa - Relatório Conclusivo (Janeiro/1986), cujo teor perpassa desde as condições estruturais e funcionais da escola brasileira às condições didático-pedagógicas do ensino e da aprendizagem de Língua Portuguesa. $\mathrm{Na}$ seção "Orientações metodológicas", destaca-se que:

No que concerne ao ensino da Língua Portuguesa, então, o objetivo último é possibilitar a todos os alunos, a todos eles, o domínio da língua de cultura para que este primeiro obstáculo possa ser transposto. Assim, tendo presente este objetivo último, cuja concretização se revelará na expressão oral e escrita dos alunos, as atividades escolares deverão centrar-se, no $1^{\circ}$ grau, em três práticas interligadas: a prática da leitura de textos; a prática da produção de textos; a prática da análise linguística. A prática permitirá ao aluno o convívio com a língua de cultura e, ao mesmo tempo, pelos diferentes textos usados - obras literárias, textos jornalísticos, propagandas, ensaios curtos, etc. -, o 
convívio com formas de expressão em que predominem diferentes funções da linguagem: emotiva, estética, representativa, argumentativa, etc. A segunda prática levará o aluno produzir textos, orais ou escritos, em que ele se exprimirá para outros, dialogando, debatendo, escrevendo e descrevendo suas experiências. A terceira prática, tomar o texto do aluno como base para o trabalho de análise linguística, lhe permitirá comparar diferentes variedades linguísticas e, no interior destas diferentes estruturas textuais, frásicas ou vocabulares que, mantendo a variedade que já dominava, lhe possibilitará chegar à expressão na língua de cultura. (BRASIL, 1986, p. 13-14; grifos do relatório)

De acordo com Luz-Freitas (2004), a constituição da Língua Portuguesa enquanto disciplina curricular, assim como as reformas educacionais dessa disciplina, sempre se orientaram, mais por motivos políticos, sociais e econômicos, que por razões teóricas em si. Dessa maneira, tanto a política linguística subjacente ao ensino de Língua Portuguesa quanto as suas reformas educacionais pautaram-se na perspectiva de que favorecer a competência do aluno em relação à linguagem e à língua poderia assegurar-lhe um progresso pleno e, por decorrência, um progresso para o país. Portanto, de um ensino pautado meramente na abordagem de conteúdos gramaticais, uma abordagem descontextualizada de metalinguagem, dado que os alunos já possuíam uma familiaridade com a variedade padrão, passou-se a privilegiar, entre as décadas de 80 e 90 , um ensino embasado em práticas de leitura e de escrita que tomam o texto como instância básica, tendo em vista a necessidade de inserção do aluno no circuito de produção e de circulação de práticas letradas.

Se, por um lado, as reformas educacionais foram baseadas em um novo perfil de aluno para reconfigurar o ensino de Língua Portuguesa, por outro, essas reformas criaram um novo perfil de professor, conforme mencionamos anteriormente ao abordarmos os documentos oficiais do Ensino Básico. Trata-se de um perfil de professor que estivesse instrumentalizado em termos teóricos e pedagógicos para levar a bom termo este ensino, tendo por orientação metodológica a instância do texto. Portanto, um professor que pautasse a sua prática de sala de aula na dimensão discursiva e interacional da linguagem, vinculando a gramática ao texto, e vice-versa. Entretanto, essa perspectiva de ensino não implicou efeitos à sala de aula em curto prazo, já que, para tal fim, estava em jogo a formação acadêmica do professor. Na perspectiva deste trabalho, estava em jogo o processo de constituição subjetiva de professores por esses documentos, tendo em vista a ancoragem que esse processo estabelece, a partir da rede de identificação dos professores.

Algumas pesquisas realizadas por estudiosos da Linguística, da Linguística Aplicada e da Educação enfocaram e problematizaram a perspectiva do texto, como pretexto para outras finalidades, no ensino de Língua Portuguesa. Por um lado, introduziu-se o texto, na sala de aula, para se insistir na abordagem descontextualizada de conteúdos gramaticais e sua metalinguagem, dado o movimento metodológico de se recorrer a fragmentos isolados do texto. Por outro lado, o texto foi tomado como possibilidade de exploração de outros assuntos que o tangenciavam, que, em muitos casos, não recebiam o devido tratamento por meio da fundamentação da leitura a partir de indícios do próprio texto. Lajolo (1985), por exemplo, destacou que a abordagem do texto, como meio de trabalho da leitura em sala de aula, está a serviço de outros fins que não o da dissecação e o da análise de sua composição interna. De acordo com essa pesquisadora, a presença do texto, na instância discursiva da aula, acaba sendo artificial, 
pois se trabalha o texto, pedagogicamente, para imitar os recursos estilísticos, para realizar análise sintática, para procurar palavras desconhecidas em dicionários, para aprender modelos de conduta moral.

Chiappini (1997), ao problematizar a relação entre o ensino de gramática e de literatura, também ressaltou a tendência que se constituiu em torno da perspectiva do texto, como pretexto para outras finalidades. Segundo ela, recorreu-se ao texto, sobretudo ao texto literário, para trabalhar meramente certos aspectos da gramática do Português, buscando-se, em primeira instância, tornar as aulas de gramática mais interessantes. Seja para mostrar o modelo de construção sintática possível, seja para mostrar as exceções consentidas pela licença poética, o texto literário foi abordado de modo fragmentário na instância discursiva da aula, acarretando a divisão entre ensino de gramática e de literatura. Consideremos, a seguir, as palavras da própria autora:

Ontem, como hoje, dificilmente conseguiríamos integrar o estudo da língua e o estudo da literatura. Sempre as aulas de língua tiveram a tendência a se concentrar na gramática, estudada abstratamente, através de exemplos soltos, de frases pré-fabricadas para os fatos gramaticais a exemplificar ou a exercitar. Às vezes, pretendendo tornar a aula de gramática mais interessante (e duplamente útil, ilustrando os seus alunos) o professor trazia (ou traz) um texto literário para nele os exercitarmos na busca de orações subordinadas ou de substantivos abstratos. Também era (e é) frequente a utilização de enunciados pescados cá e lá em contos, romances ou poemas de escritores consagrados para transformá-los, como a própria gramática o faz, em norma ou, ao contrário, em exemplos das exceções permitidas, porque provindas da pena de uma autoridade (o autor famoso). (CHIAPPINI, 1997, p. 17-18; grifos da autora)

De acordo com essa autora, tal tendência impõe questões caras e centrais ao ensino de Língua Portuguesa, como, por exemplo: a separação que é produzida, na prática, entre ensino de língua (e os tópicos de gramática) e ensino de literatura é fruto de qual demanda? Mais: essa separação seria contornável, em termos pedagógicos? Chiappini (1997) destacou que, para além de práticas tradicionais que insistem nessa separação, há professores que investem na integralização entre língua e literatura. Para tanto, trabalhase a linguagem em sala de aula por meio da leitura e da produção de textos, assegurando a possibilidade de crítica e de criação do aluno a partir de sua produção discursiva. São sempre possibilidades de integralização, segundo Chiappini (1997), que surgem das práticas particulares, e que são condizentes com a formação teórico-pedagógica do professor em exercício. Essa autora reconhece que a condição para se pensar e problematizar a superação da dicotomia entre língua e literatura nasce exatamente de práticas de sala de aula, que são sempre particulares.

À luz das duas questões sobreditas, Chiappini (1997) ponderou que toda prática se sustenta em um arcabouço teórico, na medida em que este possibilita construir objetos, definir metodologias e transformar a própria prática. Sendo assim, de acordo com ela, problematizar a dicotomia entre língua e literatura, bem como dimensionar uma possível superação, exige uma circunscrição conceitual em torno desses termos. Dependendo da natureza conceitual, a relação entre língua e literatura pode se orientar por uma dicotomia ou por uma transversalidade. Diante dessa orientação, por sua vez, a instância do texto pode assumir diferentes feições em termos de abordagem pedagógica. 
Para Chiappini (1997), se literatura e língua forem concebidas a partir de uma perspectiva considerada mais tradicional, aquela que busca manter a hierarquia e a individualização de certos aspectos desses conceitos, o ensino de língua e de literatura será sempre dicotomizado. Se tais termos forem perspectivados a partir de suas relações com o "trabalho com a linguagem" (CHIAPPINI, 1997, p. 23.), o ensino de língua e de literatura passa a ser possível em uma mesma prática, ou seja, em uma prática transversal. É válido ressaltar que Chiappini (1997) enfatizou a relevância e o alcance que toda teoria imprime a toda prática, conforme já destacamos. Por isso, sob seu ponto de vista, a problematização sobre o ensino de língua (e os tópicos de gramática) e de literatura, portanto, sobre as práticas de sala de aula, não seria uma questão menos teórica, já que, para ela, teoria e prática estão sempre intimamente relacionadas.

Faraco e Castro (1999) também problematizaram a perspectiva do texto, como unidade de ensino, nas aulas de Língua Portuguesa. Trata-se, de acordo com tais pesquisadores, de uma questão de natureza também teórica, embora se perceba a tentativa de se vincular essa perspectiva a uma dimensão mais prática. Se, por um lado, o texto foi introduzido nas aulas de Português, como objeto de estudo, por outro, essa introdução não assegurou o trabalho da gramática no texto, por exemplo. Não se trata, segundo eles, de pensar que essa realidade estaria em função tão somente de certo perfil de professor mal formado. Ao contrário, o próprio trabalho de abordagem do texto, na instância discursiva da aula, encerra certa complexidade.

Para circunscrever essa complexidade, Faraco e Castro (1999) destacaram que a proposta dos linguistas em eleger e em fundamentar o texto, como ponto de referência, apresentou alguns ganhos para o ensino de Língua Portuguesa. Sobretudo, porque se buscou definir e contemplar o texto, como manifestação da linguagem em uso. Entretanto, essa proposta impôs certos limites tanto aos linguistas quanto aos professores. Primeiro, porque a mudança de foco das regras e dos conceitos normativos para a instância do texto, como defenderam os linguistas, não gerou uma ruptura, inclusive terminológica, em relação à concepção de linguagem dos gramáticos. Segundo, porque a abordagem práticointuitiva dos fatos gramaticais do texto em proveito da exploração intensa de regras em ocorrências descontextualizadas, como se notou no ensino das escolas brasileiras, foi interpretada como sinônimo do abandono do ensino da gramática.

Reconhecendo a pertinência tanto da tradição dos gramáticos quanto da tradição dos linguistas, portanto, sem considerá-las pelo viés de que a segunda tradição superaria a primeira, Faraco e Castro (1999) assinalaram a dificuldade que há no processo de integralização do trabalho formal com a gramática tradicional ao texto, já que são domínios específicos e, consequentemente, com abordagens metodológicas diferentes. Sem perder de vista a perspectiva teórica que essa questão envolve, esses pesquisadores assinalaram que uma maneira possível de contornar o ensino essencialmente normativo seria privilegiar a reflexão sobre a linguagem, dimensionando, no espaço de sala de aula, a sua natureza multifacetada. Para tanto, eles reportaram-se aos estudos de Bakhtin (1986) para ressaltar que a proposta interativo-textual de linguagem pode possibilitar um novo empreendimento para as aulas de Língua Portuguesa. Sobretudo, porque essa proposta concede um lugar de destaque para o processo interlocutivo, demandando dos envolvidos nesse processo uma percepção e uma reflexão da realidade da linguagem. 
Os trabalhos de Lajolo (1985), de Chiappini (1997) e de Faraco e Castro (1999), como consideramos anteriormente, dão contribuições significativas à reflexão sobre o ensino de Língua Portuguesa a partir da instância do texto. Sobretudo, dão contribuições significativas às implicações da circunscrição da Língua Portuguesa ao texto. Se é verdade que essa instância representou uma mudança de foco para o ensino, também é verdade que ela apresentou certos desafios, independentemente do perfil do professor que estivesse em questão. Claro que, a depender da formação teórica e pedagógica do professor, o alcance e os desafios do trabalho de exploração do texto, na instância discursiva da aula, assumem feições particulares e saídas contingenciais.

De agora em diante, para pensar na Língua Portuguesa, como objeto circunscrito, vamos enfocar detidamente o documento de Língua Portuguesa direcionado ao Ensino Fundamental, pois a problematização deste artigo está ancorada no estudo de caso que foi realizado em relação à prática pedagógica do professor participante da pesquisa do doutoramento. Trata-se de aulas ministradas em uma turma de nono ano de uma escola pública de educação básica. A área de Língua Portuguesa dessa escola possui, por sua vez, um documento interno que remonta os princípios dos PCN de Língua Portuguesa do Ensino Fundamental.

Vigente até os dias atuais, o documento de Língua Portuguesa do Ensino Fundamental é considerado um documento de trabalho relevante para o professor, cuja pertinência e eficácia contam, por um lado, com os direcionamentos pedagógicos precisos, em termos de proposição de conteúdos por ciclo de ensino, e, por outro, com a abertura que é dada ao professor para o momento de sua prática pedagógica em sala de aula. Portanto, esses parâmetros configuram-se, na realidade educacional brasileira, como um documento oficial, que possui um certo caráter normativo. Mais que normativo, esse documento tem uma feição de documento formativo, já que busca orientar o professor.

Apenas introduzir o texto nas aulas de Língua Portuguesa não era o bastante, como se fez no âmbito do sistema educacional brasileiro. Era preciso realizar, acima de tudo, um movimento metodológico que, de fato, resguardasse o alcance e a pertinência do texto, como fruto de uma prática social, inserida em uma ação específica, bem como a sua relevância, como objeto de ensino e de aprendizagem, garantindo a possibilidade de sua reflexão. Nos PCN de Língua Portuguesa do Ensino Fundamental, esse movimento metodológico é delineado a partir do eixo Ação $\rightarrow$ Reflexão $\rightarrow$ Ação, conforme destacaremos mais adiante. Sendo assim, a abordagem metodológica do texto compreende: o movimento de se dimensionar as diferentes práticas sociais, cujo meio de mediação é sempre um texto; o movimento de se refletir a estruturação composicional do texto, concebendo a sua composição linguística interna; o movimento de produção de outros textos, assegurando o desenvolvimento da competência discursiva do aluno.

Por estarem vinculados à reformulação do Ensino Básico de Língua Portuguesa no país, segundo já destacamos, os PCN do Ensino Fundamental acentuaram a necessidade e a eficácia do perfil de professor que tenha sua prática embasada no trabalho com o texto. Assim, nesse documento, o ensino de Língua Portuguesa é caracterizado como uma instância pedagógica que deve favorecer o trabalho e a reflexão do aluno em relação à linguagem e à língua, tendo por base diferentes textos passíveis de serem mobilizados na instância discursiva da aula. Nessa caracterização, ganha-se ênfase a perspectiva de que a abordagem inter-relacionada do domínio da linguagem e do domínio 
da língua, em sala de aula, cria condições para a plena participação social do aluno no contexto em que estiver inserido. Segundo os PCN, o domínio da linguagem, dialógico por natureza, ancora a atividade discursiva e cognitiva de comunicação entre os homens. E o domínio da língua, sistêmico por natureza, comporta uma dimensão simbólica que permite a constituição de comunidades linguísticas na sociedade. Consideremos uma passagem dos PCN que embasa esses apontamentos:

O domínio da linguagem, como atividade discursiva e cognitiva, e o domínio da língua, como sistema simbólico utilizado por uma comunidade linguística, são condições de possibilidade de plena participação social. Pela linguagem os homem (sic) e as mulheres se comunicam, têm acesso à informação, expressam e defendem pontos de vista, partilham ou constroem visões de mundo, produzem cultura. Assim, um projeto educativo comprometido com a democratização social e cultural atribui à escola a função e a responsabilidade de contribuir para garantir a todos os alunos o acesso aos saberes linguísticos necessários para o exercício da cidadania. (BRASIL, 1998, p. 19)

Dependendo do grau de letramento do aluno, a abordagem desses domínios, na instância discursiva da aula, pode acentuar o contato do aluno com as práticas letradas, permitindo o aprimoramento de competências e de habilidades linguístico-discursivas, bem como a participação efetiva do aluno no seu contexto de atuação social. Conforme é ressaltado nos PCN, a escola deve identificar o grau de letramento dos alunos, para que o trabalho com linguagem e com a língua ganhe certa particularidade e certo alcance.

Os PCN do Ensino Básico estão estruturados em duas partes, que são intimamente relacionadas. A primeira parte concerne, notadamente, à apresentação de informações provenientes de diferentes campos da Linguística, dada a necessidade de se caracterizar a área de Língua Portuguesa, vinculando-as à instância de ensino e de aprendizagem. A segunda parte refere-se à especificação dos conteúdos de Língua Portuguesa por ciclo de ensino, tendo em vista os eixos temáticos "Prática de escuta de textos orais e leitura de textos escritos", "Prática de produção de textos orais e escritos", "Prática de análise linguística". Nessa parte, apresentam-se alguns parâmetros didáticos para a abordagem pedagógica do professor, resguardando a natureza do conteúdo em questão e o enfoque do movimento metodológico de Ação $\rightarrow$ Reflexão $\rightarrow$ Ação, a ser instaurado na instância pedagógica pelo professor. Vejamos uma passagem dos PCN que fundamenta essas observações:

Os princípios organizadores dos conteúdos de Língua Portuguesa (USO à REFLEXÃO à USO), além de orientarem a seleção dos aspectos a serem abordados, definem, também, a linha geral de tratamento que tais conteúdos receberão, pois caracterizam um movimento metodológico de AÇÃO à REFLEXÃO à AÇÃO que incorpora a reflexão às atividades linguísticas do aluno, de tal forma que ele venha a ampliar sua competência discursiva para as práticas de escuta, leitura e produção de textos. Nesse sentido, o professor, ao planejar sua ação, precisa considerar de que modo as capacidades pretendidas para os alunos ao final do ensino fundamental são traduzidas em objetivos no interior do projeto educativo da escola. São essas finalidades que devem 
orientar a seleção dos conteúdos e o tratamento didático que estes receberão nas práticas educativas. (BRASIL, 1998, p. 65)

Para construírem a caracterização da Língua Portuguesa como objeto de ensino e de aprendizagem, tomou-se, por princípio, a concepção de que a língua possui variações, que implicam a existência de diferentes variedades linguísticas no âmbito do sistema linguístico do português; são variedades que não assumem, do ponto de vista linguístico, uma valoração entre si, mas, sim, uma valoração social, dada a constituição cultural do Brasil. Também se tomou, por princípio, a perspectiva de que a comunicação humana se constitui sempre a partir de textos, que se pautam em fatores de textualidade, a saber: coesão, coerência, estrutura formal do texto; situacionalidade, aceitabilidade, informatividade, intertextualidade, intencionalidade, estrutura pragmática do texto. Ainda se tomou, por princípio, a perspectiva de que os textos, para se constituírem e circularem socialmente, prendem-se a formatos e a funções institucionais específicas. São textos que se materializam a partir de "gêneros de texto", para usarmos a terminologia que aparece nos PCN. Vamos adotar, neste artigo, essa terminologia, inclusive quando fizermos menção, mais adiante, aos estudos do Grupo de Genebra.

Ao perspectivarem a Língua Portuguesa, como prática pedagógica, atribui-se importância a três variáveis, no âmbito dos PCN, quais sejam: o aluno, o conhecimento, o professor. Trata-se, portanto, de uma tríade em que os elementos possuem papéis específicos e relacionados, ao mesmo tempo. O "aluno" assume o papel de indivíduo da ação de aprender, atuando com e sobre o conhecimento. O "conhecimento", contemplado nas referências curriculares, concerne a conhecimentos discursivo-textuais e linguísticos estruturadores das práticas sociais, que são alçados a objeto de ensino e de aprendizagem. O "professor" exerce o papel de mediador entre os outros dois elementos por meio de sua prática educacional.

Se, por um lado, a variável "conhecimento" a ser ensinado e apreendido ganha certa perspectiva de lugar-comum a qualquer instância pedagógica, considerando a perspectiva subjacente ao documento, por outro, as variáveis "aluno" e "professor" contam com uma particularização, já que entra em jogo, na instância discursiva da aula, a constituição humana dos que estão concernidos por ela. Trata-se de pensar, acima de tudo, na perspectiva de que aluno e professor possuem uma formação sociocultural que imprime efeitos à instância pedagógica em si. Essa constituição humana sustenta a possibilidade de identificação ou não entre "aluno-conhecimento-professor". Assim, essa tríade está ancorada em um jogo complexo de relação, que dependerá dos que estão envolvidos na relação para se constituir.

No caso do aluno, é ressaltado, nos PCN, a necessidade de se levar em consideração a fase de adolescência em que os alunos se encontram. Enfatiza-se a ideia de que o trabalho pedagógico com a linguagem deve respeitar algumas especificidades dessa fase, como, por exemplo, a dimensão afetivo-emocional do adolescente que está em formação. Portanto, o ensino de Língua Portuguesa teria como uma de suas funções oportunizar ao aluno o contato com textos orais e escritos em que opiniões, valores e saberes, materializados de diferentes formas nesses textos, fossem objeto de reflexão.

No caso do professor, ao dimensionarem o tratamento didático dos conteúdos, destaca-se, na segunda parte dos PCN, que a formação dele é decisiva para a implementação de mudanças no ensino de Língua Portuguesa. A formação acadêmica do 
professor produz efeitos para a instância discursiva da aula, pois ele é convocado a responder pela mediação entre aluno e conhecimento, produzindo a seleção do conhecimento e o modo de transmissibilidade deste, bem como a avaliação da aprendizagem do aluno. Portanto, o professor é convocado a responder por uma prática de sala de aula, que conta, em última instância, com a organização do discurso de sua aula, ou seja, com o modo como o conhecimento é tematizado na instância discursiva da aula.

Com o compromisso de produzir um discurso oficial para o ensino e a aprendizagem de Língua Portuguesa, os PCN abordam a relação entre "alunoconhecimento-professor" como pressuposta e orientada por um movimento metodológico de Ação $\rightarrow$ Reflexão $\rightarrow$ Ação, aludido anteriormente. Vislumbra-se a prática pedagógica de Língua Portuguesa em função de um equilíbrio na abordagem do professor em relação aos eixos ${ }^{5}$ temáticos que constituem essa disciplina. Entretanto, é sabido que essa relação pode ganhar desdobramentos particulares, quando se trata de pensar a instância discursiva da aula. Primeiro, porque aluno e professor, conforme já destacado, possuem formações humanas específicas. Segundo, porque a instância discursiva da aula encerra um caráter contingencial, que implica e que convoca um modo particular de relação discursiva com os saberes abordados na aula, levando o professor a priorizar um dos eixos em proveito dos demais. Terceiro, porque a formação teórica e pedagógica do professor intervém no modo como se estabelece a exploração metodológica de cada eixo.

Pautar a prática pedagógica no movimento metodológico de Ação $\rightarrow$ Reflexão $\rightarrow$ Ação, exige que o professor produza, por sua vez, movimentos de associação entre os saberes tematizados, em sala de aula. Assim, esses movimentos podem permitir a ele abordar o aspecto transversal do conhecimento, considerando a natureza dos três eixos temáticos propostos para o Ensino Fundamental.

Muitos trabalhos inscritos na área da Educação e no campo da Linguística Aplicada, imbuídos muitas vezes de uma prescrição, apostaram em meios pedagógicos para que o ensino e a aprendizagem de Língua Portuguesa fossem orientados pelo referido movimento metodológico. Podemos citar a perspectiva de abordagem que se constituiu em torno da transposição didática de gêneros de texto, por exemplo, tendo em vista a influência da Escola de Didática francesa. Trata-se de uma maneira de tomar o texto como ponto de partida e de chegada para o ensino de Língua Portuguesa. Nessa abordagem, caberia ao professor considerar o texto como instância de trabalho, de modo a explorar a função social do gênero de texto e os elementos discursivo-textuais e linguísticos que estruturam o plano composicional do gênero. Desse modo, assume-se a tarefa de instrumentalizar o aluno em relação à produção e à recepção de variados gêneros de texto, assegurando a implementação de um novo ensino para a Língua Portuguesa, conforme se busca com a proposição dos PCN.

A perspectiva da transposição didática de gêneros de texto é postulada por Dolz e Schneuwly (2004), por Bronckart (2003), e por outros pesquisadores do Grupo de Genebra, considerando os fundamentos do Interacionismo Sociodiscursivo (ISD). Esse grupo é formado por pesquisadores europeus que postulam os gêneros de textos, como

\footnotetext{
${ }^{5}$ Segundo já mencionamos, os eixos temáticos estruturadores da área de Língua Portuguesa, no Ensino Fundamental, são estes: "Prática de escuta de textos orais e leitura de textos escritos", "Prática de produção de textos orais e escritos", "Prática de análise linguística".
} 
instrumento de aplicação para o ensino. Assim, pautados na teoria psicológica de Vygotsky, esses teóricos partem da concepção de que os processos de desenvolvimento humano se prendem a pré-construídos humanos que são socialmente elaborados e, permanentemente, ressignificados a partir da instância do agir. A linguagem assume papel e função relevantes, nesse desenvolvimento, já que é ela quem medeia a natureza e a organização do agir e das interações humanas.

Desse modo, ao enfocar a questão específica dos gêneros de texto, Bronckart (2003) assevera que está na base do desenvolvimento humano uma imersão contínua a diferentes textos pré-existentes. E esses textos, pela própria dinâmica das atividades sociais e pelas transformações que seus produtores imprimem a eles, estão em permanente transformação. Portanto, para ele, caracterizar esses textos do ponto de vista linguístico só se torna plausível e pertinente se for feito em termos de eleição de um modelo teórico. Conforme Bronckart (2003), a diversidade teórica dos gêneros e a profusão de ocorrência concreta dos textos engendram um problema de natureza metodológica, que seria o de definir, classificar e identificar as características básicas dos textos. Logo, instaura-se uma circularidade metodológica, pois as características de cada modelo sempre são construídas por meio da comparação de diferentes modelos, tomando por base as semelhanças e as diferenças entre eles. Consideremos, a seguir, as próprias palavras de Bronckart (2003, p. 55):

a partir de um universo de textos intuitivamente classificados em gêneros, é possível proceder a um estudo empírico de suas características (linguísticas, principalmente) e formular um primeiro modelo de regras que as regem. A comparação entre modelos pode fazer aparecer parentescos ou divergências não observadas à primeira vista; regras relativas ao funcionamento de certas unidades podem ser deduzidas de novas regras; dessa maneira se elaboram "modelos de gêneros" ou "gêneros teóricos" cuja validade pode ser testada por um retorno aos dados empíricos, podendo esse processo de teste de hipóteses se estender ao infinito.

Se a definição, a classificação e a identificação dos gêneros de texto já se mostram complexas, segundo Bronckart (2003), a sua transposição didática, por sua vez, também resguarda uma certa complexidade. Bronckart e Plazaolla Giger (1998) destacam que a transposição didática não pode ser pensada em termos de uma mera aplicação de uma teoria científica ao ensino. Ao contrário, a transposição didática põe em perspectiva um conjunto de transformações que os conhecimentos científicos precisam sofrer quando se busca ensiná-los e fazê-los compreendidos. Eles podem sofrer deslocamentos, rupturas e modificações.

Esses teóricos, sem perderem de vista os trabalhos de Chevallard (1991), ponderaram que a transposição didática traz à tona a instância do "saber científico", aquele produzido no seio das teorias científicas pelos cientistas, a instância do "saber a ser ensinado", aquele contemplado por programas curriculares e por livros didáticos, e a instância do "saber ensinado", aquele que recebe um tratamento pedagógico por parte do professor e, por sua vez, é, supostamente, aprendido pelo aluno. Cada uma dessas instâncias comporta complexidades particulares e, ao mesmo tempo, complexidades que se inter-relacionam. 
No caso específico do ensino de línguas, em conformidade com os princípios da teoria da transposição didática, percebe-se que a variedade de abordagens científicas em torno de um mesmo tema cria conceitos diferentes, muitas vezes antagônicos, e metodologias específicas. Entretanto, ao elaborarem muitos programas oficiais de ensino e de aprendizagem, o "saber a ser ensinado" é constituído a partir de informações linguísticas fragmentárias, gerando, em muitos casos, até uma incoerência na proposta global do programa. Nota-se que a relação produzida entre as práticas de linguagem, os modelos teóricos que se dão a conhecer dessas práticas e a constituição desses modelos, como objeto de ensino e de aprendizagem, acaba implicando uma associação imediata e sem resguardar as devidas proporções. Essa associação imediata é percebida no caso da tão propalada perspectiva de que a abordagem dos gêneros de textos, em sala de aula, deve preparar o aluno para as práticas de linguagem vigentes na sociedade.

Quando se trata de pensar na terceira instância, a do "saber ensinado", a complexidade é fruto da relação entre as variáveis "aluno" e "professor", que sofre uma triangulação a partir da variável "conhecimento", conforme já ressaltamos anteriormente. Dimensionar essa terceira instância, portanto, convoca enfocar a instância discursiva da aula em si, sobretudo, a relação discursiva do professor com os saberes, tendo em vista a relação discursiva entre professor e aluno frente ao saber. Assim, dependendo dos envolvidos nessa instância discursiva, a transposição didática dos gêneros de textos pode ganhar diferentes orientações; inclusive, para retomar Lajolo (1985), a abordagem didática do texto, em aula, pode estar em função meramente de pretextos para outros fins que não o da dissecação e análise textuais, ou mesmo da não integralização da gramática normativa. Essa modalidade de abordagem acaba acarretando uma desarticulação pedagógica entre os eixos temáticos estruturadores do ensino e da aprendizagem de Língua Portuguesa.

Os teóricos da Escola de Didática francesa desenvolveram a perspectiva do ensino baseado na "sequência didática", buscando contornar o problema que também foi pensado por eles, na década de 80 , em relação ao tex to como pretexto. Para tanto, o ensino deveria ser orientado por uma sequência de atividades progressivas e integradas a um tema, a um objetivo geral, de modo a assegurar uma descompatibilização dos conteúdos e das competências e habilidades projetadas para o ensino. Nessa década, ainda não se pensava a "sequência didática" com base nos gêneros de texto. Posteriormente, a partir da década de 90, esses teóricos vincularam a "sequência didática" aos gêneros de texto, criando a perspectiva da "sequência didática de gêneros". Bronckart (2006), ao ressaltar o aporte do Interacionismo Sociodiscursivo (ISD), afirmou que as sequências didáticas de gêneros de texto possibilitam engendrar meios de mediação formativa para o ensino. Sempre, por meio de um modelo padrão, a sequência didática privilegia a arquitetura textual do gênero. Consideremos as próprias palavras de Bronckart (2006, p. 116):

O segundo momento foi aquele de elaboração de métodos conforme este programa, o que deu lugar à concepção e à realização de múltiplas sequências didáticas, ou seja, de séries de lições-tipo centradas sobre o domínio de um gênero textual determinado visando dominá-lo nas condições de utilização social, e, sobre a base do modelo de arquitetura textual mencionado acima, resolver os problemas técnicos (ou linguísticos) de sua organização (Dolz, Rosat et Schneuwly, 1991; Dolz et Schneuwly, 1998; Schneuwly et Dolz, 1997). Estas duas primeiras etapas visavam essencialmente a uma racionalização do projeto de 
ensino de línguas, sobre o ângulo de seus conteúdos e de seus métodos, nesse sentido, ressaltava de preferência o que as correntes ergonômicas contemporâneas qualificariam de "trabalho prescrito". (Tradução nossa.)

No âmbito educacional brasileiro, além de os PCN estarem centrados na questão dos gêneros de texto, conforme vínhamos considerando anteriormente, os livros didáticos também passaram a considerar o texto como ponto de aplicação. Instituiu-se o Programa Nacional do Livro Didático (PNLD), com a finalidade de implementar uma política governamental em torno da seleção e da distribuição do livro didático nas escolas brasileiras públicas, entre outras medidas. Os livros didáticos precisavam levar em consideração o desenvolvimento de uma sequência didática, elegendo um modelo didático de gênero, considerando a integração dos três eixos norteadores do ensino e da aprendizagem de Língua Portuguesa.

É possível enfatizar que tanto os documentos oficiais do Ensino Básico quanto o PNLD, entre outras ações do governo brasileiro, buscam criar uma política linguística de ensino para o professor de Língua Portuguesa, no sentido de orientá-lo. No entanto, é sabido que o espaço de sala de aula vai comportando práticas particulares, conforme já destacamos anteriormente. Se retomarmos a tríade "professor-conhecimento-aluno", podemos dizer que as variáveis "professor" e "aluno" fazem com que a instância discursiva da aula seja cada vez provisória e particular. Assim, contando com um aparato governamental sobre o ensino e a aprendizagem, as aulas de Língua Portuguesa vão se constituindo, na medida que professor e aluno exerçam seu papel. Não se trata de pensar, neste momento, em papéis idealizados, como se percebe a partir da projeção que se produz em relação ao professor, ao conhecimento e ao aluno. Trata-se de pensar, acima de tudo, que tanto professor quanto aluno possuem uma formação humana que ancora um jogo complexo de identificação entre eles, entre o objeto alvo de ensino e de aprendizagem, que no caso é a Língua Portuguesa e seus eixos estruturadores, segundo já aludimos neste artigo.

Para concluirmos esta seção, é possível salientar que a Língua Portuguesa, para ser instituída e constituída na condição de objeto de ensino e de aprendizagem, contou com a intervenção do Estado no currículo escolar. Como vínhamos considerando, a contingência histórica e política foram decisivas para o advento do texto, como ponto de partida e de chegada para as aulas de Língua Portuguesa em proveito do ensino tradicional de leitura e de escrita. E vínhamos considerando, também, que a apropriação de conhecimentos linguísticos modernos, tendo por base a abertura governamental para as equipes de trabalho de (re)elaboração do documento, com assessoria de teóricos da linguagem, ajudou a recolocar em outros termos o ensino de gramática normativa. A gramática normativa, eclipsada em seu ensino tradicional, no âmbito desse documento,

\footnotetext{
${ }^{6}$ Le deuxième temps a été celui de l'élaboration de méthodes conformes à ce programme, ce qui a donné lieu à la conception et à la réalisation de multiples séquences didactiques, c'est-à-dire de séries de leçonstypes centrées sur la maîtrise d'un genre textuel déterminé et visant à en maîtriser les conditions d'utilisation sociale, et, sur la base du modèle d'architecture textuelle évoqué plus haut, à résoudre les problèmes techniques (ou linguistiques) de leur organisation (Dolz, Rosat et Schneuwly, 1991; Dolz et Schneuwly, 1998; Schneuwly et Dolz, 1997). Ces deux premières démarches visaient de la sorte essentiellement à une rationalisation du projet d'enseignement des langues, sous l'angle de ses contenus et de ses méthodes, et en ce sens, relevait plutôt de ce que les courants ergonomiques contemporains qualifieraient de "travail prescrit".
} 
por exemplo, constituiu-se, como um material que toca o recalque, como destacamos anteriormente. Para aludirmos à epígrafe deste artigo, a gramática passou a guardar um "mistério" para muitos, como poetizou Drummond (1996). E o modo de se enfrentá-la, dada a contingência histórica e política de emergência dos PCN, só se estabelece a partir da mediação do texto.

\section{Da instância do professor}

Nesta seção, tendo por base a entrevista realizada com o professor da Educação Básica, mobilizamos alguns dizeres recortados de sua enunciação falada, buscando mostrar o modo como o professor tematiza algumas questões sobre o ensino em geral e sobre questões pontuais do ensino de Língua Portuguesa, como, por exemplo, a relação entre língua e gramática normativa em seu fazer pedagógico. A apresentação de alguns dizeres do professor, neste ponto, está em função de se mostrar os diferentes efeitos da identificação do professor com as atividades artísticas, sendo a literatura um meio de expressão dessas atividades, e com a gramática normativa. Acima de tudo, está em função de se mostrar como a política linguística acerca da Língua Portuguesa opera efeitos no modo como o professor enuncia o seu objeto de trabalho, no caso específico a Língua Portuguesa.

No âmbito dessa política linguística, demos ênfase aos PCN, de Língua Portuguesa, do Ensino Fundamental, já que esse documento figura como objeto importante para o professor entrevistado e para a escola em que ele atua. Conforme mostraremos mais adiante, a alusão aos PCN, em suas enunciações faladas, nasce como uma demanda dele. Além disso, em muitos momentos da entrevista, algumas discursividades sobre o ensino de Língua Portuguesa são (re)atualizadas, sendo os PCN um documento propalador delas. Uma delas, como mostraremos mais adiante, é a de que esse ensino deve considerar e abordar a questão da variação linguística, de modo a (re)colocar em outros termos o ensino da variedade linguística padrão.

A partir das enunciações faladas do professor lidando já com as possibilidades e com os limites dos enunciados que delas resultam, vamos fazer um batimento entre descrever aspectos da materialidade linguística e interpretar os recortes produzidos a partir da materialidade. Discursivamente, interessa-nos tecer relações de sentido, tendo a materialidade como ponto de ancoragem, buscando sustentar o ponto de problematização deste artigo: se, por um lado, há uma circunscrição imaginária em relação à Língua Portuguesa, como objeto de ensino e de aprendizagem, por outro, há uma posição discursivo-enunciativa a ser exercida pelo professor, que aponta para as identificações que o constituem. A depender da posição exercida, o ensino de Língua Portuguesa pode ganhar contornos específicos, apontando para um modo particular de composição dessa língua como objeto de trabalho do professor.

Neste ponto, buscando caracterizar algumas questões pontuais da relação do professor com a Língua Portuguesa, na condição de objeto de ensino, vamos apresentar alguns recortes discursivos (RD) da entrevista que realizamos com ele. A entrevista foi realizada no dia 17 de novembro de 2011, na escola foco da pesquisa. Tratava-se, na verdade, de mais um momento de contato com o professor, pois, desde maio de 2011, 
fomos acompanhando, cotidianamente, o seu trabalho pedagógico em turmas de nonos anos escolares. A entrevista se pautou em um roteiro prévio de perguntas que tematizava questões mais pontuais da área de Língua Portuguesa e de seu ensino até questões mais gerais, em termos didático-pedagógicos. No contraturno de suas aulas, o professor foi entrevistado no laboratório de Língua Portuguesa da escola; fizemos uso de uma filmadora para registrarmos áudio e imagem do professor, quando do momento de responder às questões. Depois, procedemos à transcrição do áudio, que seguiu a mesma notação ${ }^{7}$ de transcrição das aulas. Por questão de espaço, as aulas não serão abordadas neste artigo.

Antes de perguntá-lo sobre o que seria ser professor de Língua Portuguesa em específico, fizemos a ele uma pergunta mais genérica sobre o que seria ser professor para ele. Na verdade, com essa pergunta, pretendíamos perceber qual (ou quais) atributo(s) que o professor tematizaria em sua resposta, ao tentar definir de modo geral o que seria ser professor; nos termos deste trabalho, seria perceber uma possível representação de professor para ele, de maneira a mostrar qual (ou quais) discursividades produzem uma possível representação de professor. Em forma de RD, apresentamos, a seguir, trechos da resposta do professor:

\section{RD1}

$\mathrm{P}$ : Bom! Eu acho que ahhhh // o trabalho do professor para mim tá muito ligado com uma.. uma série de atividades artística que eu venho desenvolvendo, desde que eu era mais jovem, eu estudei música, estudei poesia, estudei desenho, uma série de outras atividades, assim!, e a atividade como professor, éhhh!, vamos dizer assim, é uma alternativa, uma possibilidade profissional maior que você tem pra poder lidar com esse universo das artes e tal e você poder ter aí um// uma situação financeira razoável para você poder tocar sua vida também. Aqui, no Brasil aí, esse universo das artes, ele é um pouco castigado, vamos dizer assim, certo! Então, é muito difícil você conseguir sobreviver bem, com atividades artísticas pura e simplesmente.

E: Sei!

P: Então isso que me conduziu a Letras e isso que me conduziu a trabalhar inclusive bastante a literatura que é uma das coisas que eu faço nos meus cursos.

(Entrevista, 17/11/2011; grifos nossos.)

É possível perceber, a partir desse RD1, que o professor já vincula o plano geral de sua definição a sua própria experiência docente, mais notadamente a seu percurso nas atividades ligadas às artes. Parece-nos, à luz dos dizeres do professor, que ser professor exigiria um contato enfático com as artes; ou melhor, de posse da vinculação entre "atividade como professor" e "é uma alternativa, uma possibilidade profissional maior que você tem pra lidar com esse universo das artes [...]", acionada pela expressão "vamos dizer assim", podemos nos perguntar: a docência seria decorrente desse contato com as artes ou uma alternativa financeira, no caso desse professor, tendo em vista a não valorização das atividades artísticas no Brasil? Talvez essa sedução e o engajamento pelas

\footnotetext{
${ }^{7} \mathrm{Na}$ esteira de Valdir Flores (2006), assumimos, neste artigo, a perspectiva de que o ato de transcrição da entrevista, até mesmo pela necessidade de expormos alguns aspectos no trabalho de análise, já é outro momento de enunciação. Um momento também singular daquele que transcreve. Em vista disso, adotamos a seguinte notação para a transcrição: // para expressarmos pausas curtas; $E$ para indicar Entrevistador; $P$ para indicar Professor.
} 
artes impliquem um modo bem particular, no caso desse professor, de identificação e de fascínio dele pela literatura - instância que se abre, por excelência, para certa relação com a expressão artística.

A ocorrência da expressão linguística "inclusive bastante", em destaque no RD1, por meio do recurso itálico, chamou-nos a atenção. Essa expressão aparece no segundo movimento interlocutivo do professor. Essa expressão se constitui de uma relação de adverbialização entre os advérbios "inclusive" e "bastante". Essa relação de adverbialização produz um efeito de ênfase, de intensidade, quando o professor se referiu a seu trabalho com a literatura; sobretudo, pela ocorrência do advérbio "inclusive". A menção que ele faz à literatura, e também à área de Letras, é encabeçada, no RD1, respectivamente, pelo operador remissivo neutro, o "isso". Frente aos dois polos que ele destacou, anteriormente em sua enunciação falada, quais sejam: o das atividades artísticas e o da questão financeira, estamos inclinados a ler-interpretar a ocorrência desse operador neutro, como uma questão que não se fecha.

Considerando esse não fechamento de sentidos, uma não coincidência de sentidos que se abre a uma equivocidade, esse dizer do professor interroga-nos: qual polo o conduziu às Letras e ao trabalho contundente com a literatura? Trata-se, a nosso ver, de uma faceta, ousamos dizê-la enigmática, da narrativa que o professor produz acerca de sua experiência; experiência de artista ou de professor? - a considerar o olhar desse professor, talvez se tratasse da conjugação dessas duas experiências.

Também perguntamos a ele: o que seria ser professor de Língua Portuguesa? Com essa pergunta, gostaríamos que ele discursivizasse a sua concepção sobre a possível especificidade que o trabalho do professor de Língua Portuguesa pode e/ou deve ter em termos do que se espera dessa área disciplinar. Vejamos, a seguir, a resposta dada pelo professor ao questionamento produzido:

\begin{abstract}
RD2
P: Bom! Professor de Língua Portuguesa, eu acho uma coisa interessante porque a gente tá, a gente tem assim ah! // vamos dizer assim ah! a intenção de, no fundo, preservar uma tradição, quer dizer: preservar as tradições ligadas a práticas de nossa língua, né!, e conseguir fazer com que essas tradições elas não morram, que elas permaneçam vivas, não é? Talvez alguns conteúdos do Português não sejam muito propícios a isso, como, por exemplo, conteúdos que enfatizam demais a gramática normativa e tal. Mas, eu acho que, num ponto de vista geral, você trabalhar com Língua Portuguesa, né!, você tá, de alguma maneira, buscando um resgate de uma tradição e buscando tornar essa tradição viva pros alunos com que você tá trabalhando.

E: E O que seria essa tradição, professor!

P: Essa tradição, quando eu me refiro a isso, eu to falando da tradição cultural heterogênea, certo!? Que envolve uma série de formas, inclusive artísticas, éhhh, costumes, valores e também, no meio disso tudo, a língua.
\end{abstract}

(Entrevista, 17/11/2011; grifos nossos.)

Nesse RD2, ser professor de Língua Portuguesa estaria para a perspectiva de se buscar práticas de sala de aula que dimensionassem a preservação de uma tradição, mais 
especificamente de um legado atinente às práticas de nossa língua. Considerando os dizeres produzidos pelo professor, esse dimensionamento se manifesta a partir de uma dobra discursiva em seu dizer, encabeçada pela expressão "quer dizer", em destaque, no RD2, por meio do recurso itálico, quando ele desdobra "preservar uma tradição" para "preservar as tradições ligadas a práticas de nossa língua".

Sob a perspectiva do professor, essa busca pela tradição na aula de Língua Portuguesa pode encontrar certos meios privilegiados de abordagem, contudo, para ele, os "conteúdos", para usarmos os termos do professor, relacionados à gramática normativa não oportunizariam essa abordagem, embora talvez fôssemos levados a pensar que sim. Isso porque é sabido que, em geral, a ilustração das regras apresentadas na gramática normativa provém de ocorrências retiradas/recortadas de escritos de muitos literatos. Essa ressalva produzida pelo professor em relação à gramática normativa não nasce do nada. Ela advém de algum lugar, historicamente marcado. A separação que se fez, e ainda se faz, entre literatura e gramática, no âmbito do ensino de Língua Portuguesa, precipita, discursivamente, em sua forma mais aparente, neste momento da enunciação falada do professor. Trata-se de uma divisão de conteúdos que é dele, não no sentido subjetivista, e que expressa uma identificação dele com a Língua Portuguesa e seus eixos estruturadores. Por mais que os PCN busquem estruturar uma organização coletiva sobre esse ensino, há uma prática pedagógica que é específica.

$\mathrm{Na}$ verdade, para o professor em questão, essa tradição estaria fortemente relacionada a uma "cultura heterogênea", a qual, por sua vez, encontraria modos de manifestação a partir de formas artísticas variadas, de costumes, de valores. À luz da teoria enunciativa de Authier-Revuz (1995), poderíamos dizer que, imaginariamente, o professor pressupõe, à sua revelia, uma coincidência entre "cultura heterogênea" e "formas artísticas", "costumes", "valores". Essa suposta coincidência deflagrasse, talvez, a busca por um efeito de unidade temática acerca daquilo que ele enuncia. Entretanto, embora não tenhamos feito alusão direta às teorizações de Authier-Revuz (1995) sobre as não coincidência do dizer, é possível dizer que, na verdade, há, neste ponto do dizer do professor, uma não coincidência das palavras consigo mesmas. Trata-se de um ponto em que o sentido se abre ao diferente. As palavras, ao serem relacionadas, nessa enunciação falada, à "cultura heterogênea", ganham generalizações semânticas, e o professor passa a ser enganchado em e por uma discursividade de circulação social referente ao ensino de Língua Portuguesa: a língua possibilita o acesso à cultura.

No RD2, chamou-nos a atenção o fato de o professor dizer que a língua estaria mediando a questão da "tradição cultural heterogênea". De posse desse dizer, endereçamos a ele o seguinte questionamento: e qual papel a língua assume nesse processo? Consideremos, a seguir, dois trechos da reposta do professor, em forma de RD3 e RD4:

\section{RD3}

P: Eu acho que a língua assume, hoje em dia, ela assume um papel incrível, quer dizer, ela vai compor, com essa // com esse trabalho aí de // de.. meio de // enfretamento cultural, e etc. e tal, ela vai compor, éhhh!, // vai trazer com ela toda essa história que eu tô contando, com você, e ela vai compor de uma forma especial porque ela tem a sua objetividade, como estrutura, como língua, ela vai compor também essa // essa dinâmica difícil, né, de, de, de tensão social. Então, eu acho que 
hoje a gente tá vivendo isso de uma forma gritante, né, como nós, eh!, tudo isso que tá acontecendo em relação à introdução do papel da norma padrão, do papel da gramática, do erro, né!, que é uma coisa que na Linguística tá um pouco até desmistificada, certo!, mas que na opinião pública não está desmistificado. Então, ahh // ordem de imprensa a qualquer instante lança uma reportagem cuja a pauta é o preconceito linguístico mais descarado né, mais desaforado que a gente possa conceber. Então, quer dizer, essa luta em relação ao preconceito linguístico, ao problema da gramática, ao problema do erro, ela tem tudo a ver com isso, quer dizer, ela tem a ver com a afirmação, talvez a gente pudesse chamar de democrático, certo!, com a afirmação democrática dos vários falares que existem no Brasil sem que esses vários falares tenham que se submeter a uma hierarquia específica em relação a isso, né.

(Entrevista, 17/11/2011.)

\section{RD4}

P: Então, uma coisa que se faz, por exemplo, em sala de aula e que eu considero de extrema importância é a gente mostrar, pros nossos alunos, que // éhhh!, justamente que é uma coisa que o PCN fala muito, e tal, né, mostrar pros alunos que a norma padrão não é igual a língua e que você pod.. e que isso não é.. não tem problema nenhum com relação à isso, que dizer, não é um grande pecado que a norma padrão não seja igual a língua, ela não precisa ser, né, a norma padrão é um padrão, um padrão informal que nós usamos em determinadas situações, eu acredito que culturalmente é importante ter uma norma padrão, né!,

(Entrevista, 17/11/2011.)

De posse desses dois recortes discursivos, notamos que o professor reitera o lugar, supostamente, privilegiado para a língua diante dos embates culturais que, possivelmente, pode se deflagrar em uma sociedade. Em seus dizeres, a língua compõe um meio de "enfrentamento cultural", tendo em vista a tensão, por exemplo, entre o ponto de vista do ensino da gramática normativa e o viés da Linguística. Interdiscursivamente, permeia a resposta do professor a tão propalada ideia do preconceito linguístico, quando se trata de ensinar ou não a norma dita padrão a alunos que não têm com ela certa familiaridade. Para o professor, por um lado, se a língua se pauta em uma sistematização de suas formas, por outro, ela possui também uma parte e uma dinâmica social e que isso engendra certamente uma tensão social.

No RD3, quando o professor menciona o "problema da gramática" e o "problema do erro", notamos prontamente a operação de certas teorias que destacam a impertinência teórica de se falar em "certo" e "errado". Mais: de se restringir o ensino de Língua Portuguesa às regras normativas construídas a partir de algumas ocorrências linguísticas. Para tanto, ele menciona, por pregnância de sentido, o caso polêmico do livro didático de Língua Portuguesa, que ocorreu no Brasil no ano de 2011. Na época, ao abordar a questão dos diversos falares brasileiros, o livro reproduziu uma construção linguística em que só a primeira unidade da frase recebia a marca morfológica de plural $(-s)$. E a imprensa brasileira polemizou a questão do livro didático, questionando a pertinência ou não desse tipo de construção linguística no ensino de Língua Portuguesa. No RD3, o trecho aparece em destaque por meio do recurso itálico. 
Para melhor dizer o que fora pretendido em seu dizer (RD4), ainda que do ponto de vista do imaginário, notamos que o professor alude aos PCN para destacar a ideia de que língua e gramática normativa não são termos que se recobrem teoricamente. E essa distinção implica, fatalmente, posicionamentos didático-pedagógicos, em sala de aula, também diferentes; implica compor uma relação discursiva também diferente. Parece deflagrar, de modo mais aparente neste ponto, uma apropriação que o professor produz em relação à ideia sócio-interacionista de língua, pois ele expressa sua filiação à questão de que, socialmente, a língua segue sua dinâmica, mais ou menos tensa. De acordo com ele, o ensino de Língua Portuguesa não poderia se furtar a isso. A alusão direta aos PCN, neste momento da entrevista, configura-se como demanda do professor. Até esse ponto da entrevista, ainda não havíamos mencionado os PCN.

De modo explícito, dado o fluxo da entrevista, direcionamos ao professor em tela um questionamento sobre o modo como ele operacionaliza, em sala de aula, alguns aspectos das tendências propostas pelos PCN em relação ao ensino de Língua Portuguesa. Tomemos o próximo recorte discursivo:

\section{RD5}

E: Levando em conta essa tendência dos PCN e essa orientação dos $\mathrm{PCN}$, na sua aula, como isso ganha um estatuto de acontecimento, como isso acontece na sua aula, como que você procede em sala de aula?

P: Eu acho que eu devo puxar em sala de aula muito provavelmente assim explicitamente pra o lado de uma abertura em relação aos falares e as várias formas de se comunicar, por exemplo, toda vez que um aluno pergunta alguma coisa sobre isso ou então quando eu to tratando isso como tópico, expondo, né, é exatamente // esse argumento que eu coloco em discussão, né, então eu acredito que no meu curso pelo menos eu devo ta puxando a sardinha pro lado da língua materna, e menos da língua nacional, embora nos mantenhamos não sei // não sei se é por costume, por que a gente também ainda pensa na questão dos vestibulares, que tem uma orientação um pouco mais tradicional, mas a gente ainda pensa um pouco em relação a essa coisa, né, da língua como uma // como esse padrão com essas regras e que o aluno precisa dominar de uma certa forma, mas eu acredito que eu devo passar o tempo todo o que eu tô falando com eles que eu estou expondo as coisas pra eles ehh! // tentandooo // ah! // azeitar essa ideia de que o padrão seja a única língua aceitável, certo! Inclusive em exercícios, // inclusivee quando a gente se depara com as contradições que nos encontramos nas inscrições da gramática normativa tradicional que às vezes são bastante embaraçosas, existem certas questões de análise sintática, por exemplo, que a gramática ela não consegue resolver absolutamente e ela trata essas questões como coisas assim como se não tivesse falado naquilo.

(Entrevista, 17/11/2011; grifos nossos.)

Nesse recorte discursivo (RD5), o professor metaenuncia sua filiação ao ensino de língua materna (o que leva em conta a questão da variação linguística da Língua Portuguesa, como, por exemplo, a variedade que constitui o aluno) em proveito do ensino de língua nacional (o que está pautado no ensino de gramática normativa). Essa filiação abre horizontes para um recorte pedagógico que se detenha nos diferentes falares que o sistema linguístico do português pode comportar, bem como nos diferentes meios de que o homem pode se valer/inventar para se comunicar. Entretanto, o professor assume que, dada a exigência de muitos processos seletivos, como é o caso do vestibular, ou mesmo 
a tendência tradicional a que estamos expostos seguramente, o ensino de aspectos da gramática normativa se torna necessário no ensino de Língua Portuguesa.

Segundo o professor, essa necessidade acaba por reclamar dele, como professor, certa criticidade em relação àquilo que seria padrão no âmbito da escritura normativa do fato gramatical. Essa escritura guarda em si contradições que sua prática de sala de aula tem de enfrentar junto aos alunos, contradições adjetivadas por ele como sendo "embaraçosas", em destaque no RD5, por meio do recurso itálico, haja vista o caso de muitos aspectos da sintaxe normativa. Isso porque, sob a lógica dessa escritura, parece ser difícil sustentar outra perspectiva para os fatos sintáticos normativos estando inscrito nessa lógica.

Por fim, poderíamos destacar que o professor deixa deflagrar, nesse mo(vi)mento, uma representação do ensino de Língua Portuguesa, como o lócus de tensão entre o ensino de aspectos de língua e aspectos de gramática normativa. Por mais que ele se veja propenso, em tese, ao ensino de língua materna, ele também se vê meio que forçado a ensinar elementos da gramática normativa. Talvez ensinar Língua Portuguesa seja o lugar, por excelência, de enfrentamento social que, por sua vez, não deixa de ser uma questão também de língua.

\section{Considerações finais}

No decorrer deste artigo, buscamos mostrar que a Língua Portuguesa, na condição de objeto de ensino e de aprendizagem, passa por diferentes mediações. Interessou-nos problematizar as mediações exercidas por alguns documentos oficiais, como mecanismo de intervenção governamental no ensino, e pelo professor, a quem cabe, em última instância, responder por uma prática docente. Abordar essas duas instâncias nos permitiu dimensionar que, no Brasil, há toda uma política linguística sobre o ensino de Língua Portuguesa, cujos princípios estão assentados em algumas teorizações da Linguística moderna. É que, como destacamos no âmbito do artigo, com a mudança de perfil de aluno que a escola passou a receber, isto é, com a democratização do acesso às escolas públicas, foi necessário fazer uma passagem do que seria objeto de ensino e de aprendizagem: de conteúdos ligados à gramática normativa e à história da literatura seria preciso enfocar práticas de leitura e de escrita. A Língua Portuguesa passou a contar com uma nova circunscrição, cuja perspectiva era tornar as aulas dessa língua diferentes daquilo que se denominou de "ensino tradicional".

Essa passagem, no cenário educacional brasileiro, não se mostrou pacífica. Do ponto de vista histórico e cultural, a relação entre "gramática normativa", seu "ensino tradicional" e a "dimensão do texto" ganhou alguns desdobramentos, em termos de metodologias de ensino. É que, em termos de efeitos dos documentos oficiais, essa gramática passou a ter um (não) lugar, como mostraram muitos pesquisadores da área da Educação, da Linguística e da Linguística Aplicada. Como aludimos no artigo, a gramática normativa, em muitas práticas docentes, passou a ser evitada em aulas de Língua Portuguesa. Em função disso, baseados na perspectiva da Psicanálise freudolacaniana, dissemos que a gramática normativa se constituiu, como um material que toca o recalque. Houve todo um movimento em favor da ressignificação das aulas de Língua 
Portuguesa, de maneira a centrar-se na dimensão do texto, como ponto de aplicação metodológica. Contudo, a relação com a gramática normativa permaneceu em aberto. Ela, por estar associada diretamente a seu ensino tradicional, foi colocada de lado em muitos casos. Na verdade, buscou-se recolocar em outros termos o seu "ensino tradicional" e, não, um convite a seu abandono, ao não enfrentamento.

Ao longo do artigo, valendo-se de diferentes diretrizes oficiais, e de modo mais detido dos PCN, fomos salientando que a circunscrição da Língua Portuguesa, como objeto de ensino e de aprendizagem, orientou-se fortemente por motivos políticos, sociais e econômicos. Não houve motivos teóricos em si que justificassem determinado direcionamento. Os fundamentos teóricos, advindos de diferentes correntes conceituais, estão em função da tentativa de se ultrapassar o ensino dito tradicional de gramática normativa, por exemplo. Assim, trata-se da constituição de uma política linguística que esteve (e está) a serviço das exigências e das urgências que chegam até à escola. Sobretudo, trata-se de uma política linguística que se abre à transversalidade do ensino de Língua Portuguesa. Expande-se o ensino de Língua Portuguesa a outras variedades linguísticas.

Se, por um lado, trabalhamos com a perspectiva de que a Língua Portuguesa é mediada pela instância dos documentos oficiais, por outro, faz-se necessário pensar na mediação exercida pela instância do professor. A depender da constituição e da formação, essa última mediação ganha múltiplos contornos. No caso do professor entrevistado, vimos que uma das figurações sobre a Língua Portuguesa é aquela de uma disciplina que possibilita trabalhar e conservar toda uma tradição que a cultura em geral produziu. E que a língua em si funciona como mecanismo de "enfrentamento cultural", para usarmos os termos do próprio professor. A língua, para esse professor, assume um lugar em que a heterogeneidade se constitui, enfrenta-se.

De posse dos RD3 e RD4, percebemos, em funcionamento, o princípio da variedade linguística e suas implicações para a questão da "norma padrão", para usarmos os termos que aparecem na entrevista. E, nesse ponto, o professor faz menção direta aos PCN, deixando entrever o caráter formativo e orientador do documento. E, a poder desse documento, o professor destaca o outro lugar que a "norma padrão" assumiu no espaço de sala de aula. Trata-se de uma variedade linguística que integra a língua, não sendo a única, e que possui um papel relevante na sociedade. No RD5, dada a pergunta lançada ao professor sobre os efeitos dos PCN em sua prática docente, notamos, ainda em operação, o princípio da variedade linguística e seus efeitos para o ensino de Língua Portuguesa. Nesse momento específico, o professor destaca a pertinência que os diferentes falares passaram a ter a partir da proposição dos PCN. É preciso ressaltar que essa pergunta advém da abertura dada pela resposta do professor, conforme o RD4.

Ainda por RD5, notamos que a menção à gramática normativa, aludida pela expressão "língua nacional", só ganha um lugar em sua prática docente em função da cobrança de alguns processos seletivos, como o vestibular. E notamos, em operação, a ideia de que a gramática normativa, em muitos aspectos, assume feições "embaraçosas", para usarmos a adjetivação que aparece na entrevista. Se trabalharmos os efeitos do lexema "embaraçosa", vamos perceber o (não) lugar que a gramática assume na enunciação falada do professor. A gramática normativa, como objeto de ensino e de 
aprendizagem, traz à tona um desconforto e que, a depender do professor, pode figurar como álibi para não se abordá-la no espaço de sala de aula.

Para finalizar, é preciso marcar que esse desconforto não nasce do nada nem se trata de uma consideração apenas desse professor entrevistado, fazendo-se pensar em certo subjetivismo. Trata-se, acima de tudo, de uma questão que possui um peso histórico, de modo a produzir efeitos sobre determinadas práticas docentes. Em função dessa historicidade, é que dissemos que a gramática normativa se constitui, como um material que toca o recalque. Sendo assim, nesse movimento de circunscrição da Língua Portuguesa, a passagem de objetos de interesse remete a uma divisão, a uma disjunção, que acaba tornando a gramática normativa um ponto a (não) ser enfrentado, a depender do professor em questão. Seja como sublime, seja como abjeto, a gramática normativa segue, historicamente, produzindo efeitos nas dimensões da política linguística para a Língua Portuguesa.

\section{Referências bibliográficas}

ANDRADE, C.D. de. Antologia poética. 35a . ed. Rio de Janeiro: Record, 1996.

AUTHIER-REVUZ, J. Ces mots qui vont pás de soi - Boucles réflexives et noncoïncidences du dire. Paris: Larousse, 1995.

BAKHTIN, M. [VOLOCHINOV, V.N.]. Marxismo e filosofia da linguagem. [1986]. Trad. Bras. $3^{\mathrm{a}}$. ed. São Paulo: Hucitec.

BRASIL. Ministério da Educação. Secretaria de Educação Fundamental. Lei no 5692/71. Brasília: MEC, 1971.

BRASIL. Senado Federal. Decreto: nº 91.372. Brasília: 1985.

BRASIL. Ministério da Educação. Diretrizes para o aperfeiçoamento do ensino/aprendizagem da Língua Portuguesa - Relatório Conclusivo. Brasília: MEC, 1986.

BRASIL. Senado Federal. Lei de Diretrizes e Bases da Educação Nacional: nº 9394/96. Brasília: 1996.

BRASIL. Ministério da Educação. Secretaria de Educação Fundamental. Parâmetros Curriculares Nacionais: Português $\left(1^{\circ}\right.$ e $2^{\circ}$ ciclos do ensino fundamental). v. 3. Brasília: MEC, 1998.

BRASIL, Ministério da Educação e Desportos. Secretária da Educação Fundamental. Referencial Curricular Nacional para a Educação Infantil: Conhecimento de Mundo. Brasília: MEC/SEF, 1998.

BRASIL. Ministério da Educação. Secretaria de Educação Básica. Diretrizes Curriculares Nacionais para a Educação Infantil. Brasília: MEC/SEB, 2010. 
BRONCKART, J.-P. Pourquoi et comment analyser l'agir verbal et non verbal en situation de travail. In: BRONCKART, J.-P.; Groupe LAF (Orgs.). Agir et discours en situations de travail. Genebra: Cahiers de la section des Sciences de l'Education, n. 103, 2006, p. 9-144.

Atividades de linguagem, textos e discursos. São Paulo: Educ, 2003.

;; PLAZAOLA GIGER, I. La transposition didactique. Histoire et perspectives d'une problématique fondatrice. Pratiques, 97-98: 35-58. 1998.

CHEMAMA, R. Dicionário de Psicanálise. Porto Alegre: Artes Médicas, 1993.

CHEVALLARD, Y. La transposition didactique: du savoir savant au savoir ensigné. Grenoble: La pensée Sauvage, 1991.

CHIAPPINI, L. Gramática e literatura: desencontros e esperanças. Em: GERALDI, J.W. (Org.). O texto na sala de aula. São Paulo: Ática, 1997.

DOLZ, J.; SCHNEUWLY, B.. Gêneros orais e escritos na escola. Campinas, SP: Mercado de Letras, 2004.

FARACO, C.A.; CASTRO, G. de. Por uma teoria linguística que fundamente o ensino de língua materna (ou de como apenas um pouquinho de gramática nem sempre é bom). Revista Educar, Curitiba, n. 15, p.179-194, 1999.

FLORES, V. do N. Entre o dizer e o dito: a transcrição como modalidade de enunciação. Organon, v. 1, n. 1, Porto Alegre: UFRGS, 2006.

LACAN, J. [1974-1975]. O Seminário, R. S. I. Movimento Freudiano, 2008.

LAJOLO, M. O texto não é pretexto. Em: ZILBERMAN, R. (Org.). Leitura em crise na escola. $5^{\text {a }}$. ed. Porto Alegre: Mercado Aberto, 1985.

LEITE, J. de D. Aula de Língua Portuguesa: das identificações do professor à sua prática. 2015. Tese. Doutorado em Estudos Linguísticos. Instituto de Letras e Linguística, Universidade Federal de Uberlândia, 2015.

LUZ-FREITAS, M. de S. E a Língua Portuguesa tornou-se disciplina curricular. Disponivel em <http://www.filologia.org.br/revista/33/04.htm>; acesso em maio de 2013.

PEREIRA, R. da S. Avanços e limitações do saber: O ensino da disciplina Língua Portuguesa nos últimos 50 anos em Campo Grande, através do livro didático (19502000). Monografia. Graduação em Pedagogia. Campo Grande, UFMS, 2000. 
Artigo recebido em: março de 2016.

Aprovado e revisado em: junho de 2016.

Publicado em: agosto de 2016

\section{Para citar este texto:}

BERTOLDO, Ernesto Sérgio; LEITE, João de Deus. Língua Portuguesa: um objeto circunscrito. Entremeios [Revista de Estudos do Discurso], Seção Estudos, Programa de Pós-graduação em Ciências da Linguagem (PPGCL), Universidade do Vale do Sapucaí, Pouso Alegre (MG), vol. 13, p. 59-86, jul. - dez. 2016.

DOI: http://dx.doi.org/10.20337/ISSN2179-3514revistaENTREMEIOSvol13pagina59a86 